\title{
Balkanologie
}

Balkanologie Revue d'études pluridisciplinaires

Vol. XIII, n 1-2 | 2011

Volume XIII Numéro 1-2

\section{Europeanisation Process of Bosnia and Herzegovina : Responsibility of the European Union?}

Bedrudin Brljavac

\section{(2) OpenEdition}

Journals

Édition électronique

URL : https://journals.openedition.org/balkanologie/2328

DOI : $10.4000 /$ balkanologie. 2328

ISSN : 1965-0582

Éditeur

Association française d'études sur les Balkans (Afebalk)

Référence électronique

Bedrudin Brljavac, «Europeanisation Process of Bosnia and Herzegovina : Responsibility of the European Union? », Balkanologie [En ligne], Vol. XIII, n 1-2 | 2011, mis en ligne le 29 décembre 2011 consulté le 07 décembre 2022. URL : http://journals.openedition.org/balkanologie/2328 ; DOI : https:// doi.org/10.4000/balkanologie.2328

Ce document a été généré automatiquement le 17 décembre 2020.

Tous droits réservés 


\title{
Europeanisation Process of Bosnia and Herzegovina : Responsibility of the European Union?
}

\author{
Bedrudin Brljavac
}

\section{Bosnian Political Context and Research Question}

Bearing in mind the fact that Bosnia and Herzegovina (hereinafter, Bosnia or BiH) is seriously lagging behind other countries from Western Balkans on the way to EU membership, it seems that Bosnia is a "special case" or a sui generis country for the EU officials. For instance, a statement delivered by Milorad Dodik, the populist leader of the most popular Bosnian Serb party - the Union of Independent Social Democrats (SNSD), provides indicative signal of unclear, vague, and complex relations between $\mathrm{BiH}$ and the European Union. In fact, Dodik, with regard to appointment of Peter Sørensen as a new Head of EU Delegation to Bosnia and Herzegovina, said that he has set measures and conditions in order to create good cooperation with the European Union. In other words, Dodik asserted that Sørensen will have a partner in Republika Srpska only if the solutions for Bosnian problems are not imposed from international community ${ }^{1}$. Thus, even before the international official started his mission in Bosnia and Herzegovina, the Bosnian political elites have prepared some measures to be respected, and kept a look on his interaction and work with local political representatives. However, this is quite an unacceptable and paradoxical situation since the $\mathrm{EU}$ is in position to set the standards and measures to be implemented rather than politicians from the potential candidate and candidate countries. What we have in Bosnia is the fact that Dodik - and on other occasions, a number of local politicians from all the three ethnic communities equally, namely Bosnian Muslims, Bosnian Croats, and Bosnian Serbs - is interpreting the European standards and criteria according to their so-called "Bosnian standards" built in particularistic ideological interests. As a result, the political positions and views the Bosnian politicians hold 
clearly demonstrate the seriousness and depth of the credibility crisis that the European Union states are facing in Bosnia and Herzegovina.

2 Although it was thought that the process of European integration, which started in the aftermath of the war in 1995, would bring political stability, economic prosperity and social harmony to Bosnia and Herzegovina, it has not happened so far. In other words, most of the strategies which the EU has used in Bosnia has ended in failure, except for a new state agencies, police reform, and visa liberalisation. Thus, according to the European Commission's Progress Report for 2011 which evaluates the country's progress regarding the EU-related reforms, Bosnia and Herzegovina has been lagging behind other countries from the western Balkans - comprising today Albania, Bosnia and Herzegovina, Croatia, the Former Yugoslav Republic of Macedonia, Montenegro, Serbia, as well as Kosovo (See Table 1.1).

\begin{tabular}{|c|c|c|c|c|c|c|}
\hline \multirow[t]{2}{*}{ Country } & \multirow[t]{2}{*}{$\begin{array}{l}\text { Feasibility } \\
\text { Study }\end{array}$} & \multicolumn{2}{|c|}{$\begin{array}{l}\text { Stabilisation and } \\
\text { Association } \\
\text { Agreement (SAA) }\end{array}$} & \multirow[t]{2}{*}{$\begin{array}{l}\text { Accession } \\
\text { Application }\end{array}$} & \multirow[t]{2}{*}{\begin{tabular}{|l} 
Actual \\
Status
\end{tabular}} & \multirow[t]{2}{*}{$\begin{array}{l}\text { Start of } \\
\text { Negotiation }\end{array}$} \\
\hline & & Signature & $\begin{array}{l}\text { Entry in } \\
\text { Force }\end{array}$ & & & \\
\hline Albania & 2002 & $12 / 06 / 06$ & $01 / 04 / 09$ & 28/04/09 & \begin{tabular}{|l} 
Potential \\
Candidate
\end{tabular} & \\
\hline $\begin{array}{l}\text { Bosnia and } \\
\text { Herzegovina }\end{array}$ & 2003 & $16 / 06 / 08$ & & & $\begin{array}{l}\text { Potential } \\
\text { Candidate }\end{array}$ & \\
\hline Croatia & 2000 & $29 / 10 / 01$ & $01 / 02 / 05$ & $21 / 02 / 03$ & $\begin{array}{l}\text { Candidate } \\
\text { Country }\end{array}$ & 03/10/05 \\
\hline Macedonia & 1999 & 09/04/01 & 01/04/04 & $22 / 03 / 04$ & $\begin{array}{l}\text { Candidate } \\
\text { Country }\end{array}$ & $01 / 10 / 09$ \\
\hline Montenegro & 2005 & $15 / 10 / 07$ & $01 / 05 / 10$ & $21 / 12 / 08$ & $\begin{array}{l}\text { Candidate } \\
\text { Country }\end{array}$ & 01/10/11 \\
\hline Serbia & 2005 & $29 / 04 / 08$ & $14 / 06 / 10$ & $22 / 12 / 09$ & $\begin{array}{l}\text { Potential } \\
\text { Candidate }\end{array}$ & \\
\hline
\end{tabular}

Table 1.1 Steps of the EU Stabilization and Association Process.

Source : The Author's Contribution

While other countries from the region have made some progress towards the EU membership, Bosnian political elites have spent this time quarrelling and further increasing ethnic tensions in the country. What is more, most of Bosnian politicians have not paid expected attention to the European integration agenda as they massively focused on achievement of their short-term ethnic-nationalist interests. Without doubt, for the ruling nationalist elites, EU integration project imposes high adoption costs because it undermines their power base, entirely built on domination of ethnic 
identity. Although domestic political elites are surely to a significant extent responsible for the country's insufficient reform processes it is also of crucial importance to understand the role and responsibility of the EU concerning the country's stagnant Europeanisation. Thus, central question in this paper is: to what extent is the $E U$ responsible for the stagnant process of European integration-related reforms in Bosnia and Herzegovina?

\section{European Integration vs. Ethnic-Nationalism}

In practice, the agenda related to European integration process is not important in the political discourse among most of Bosnian political leaders. The promise and hope of European Union membership has not been a « sufficient instrument » for the Bosnian politicians to make them respect the European values, norms and rules, and make them work on their implementation into domestic policies. Although ruling political elites are from time to time making statements that their objective is the accession into the $\mathrm{EU}$, most of them are doing very little to make the country closer to Brussels. Furthermore, most of the ruling Bosnian politicians are still living in the past while the EU-related agenda should encourage them to look towards common and more prosperous and peaceful future. Such political context explicitly demonstrate deepness and seriousness of the crisis which Bosnian political sphere is confronted with since the very end of the war in 1995. Rather than focusing on issues related with the European integration and the well-being of the ordinary citizens, politicians in Bosnia emphasize emotion-appealing politics, consequently increasing inter-ethnic polarization and disputes, what clearly indicates the post-war arrogance and irresponsible political rhetoric of ethno-nationalist political representatives. As Kurt Bassuener points out, «the Dayton constitution makes leveraging fear politically profitable and politicians unaccountable. Bosnian politicians pursue their self-aggrandizing, maximalist goals at the expense of the general welfare $»^{2}$. As a result, under the monopolistic regime of nationalist political elites Bosnia has been suffering more than a decade long political status quo.

5 In other words, ethno-nationalist political parties have been dominating political sphere in Bosnia and Herzegovina from the first democratic elections held in early 1990s. Such a preference for strictly ethnic parties by BiH electorate has been repeated at each election with the only exception of those of 2000, when Social Democratic Party (Socijaldemokratska partija, SDP), one of rare examples of multi-national political parties in Bosnia, won the elections. Thus, what has happened to Bosnia is not democratic transition but rather "ethnocratic transition". As Asim Mujkić points out: "I call a community characterized by the political priority of the ethnic group(s) over the individual that is implemented through democratic self-legislation, and a community characterized by the political priority of the ethnic group's right to selfdetermination over the citizen's right to self-determination where the citizen's membership in a political community is determined by her or his membership in ethnic community, Ethnopolis. And I call the political narrative and practice intended to justify this ethnically-based social construct, ethnopolitics $\|^{3}$. Political competition for votes has been based mainly on nationalist rhetoric, and so-called politics of outbidding has continuously taken place in the post-war BiH as nationalist parties have cemented their early seize of power in successive elections ${ }^{4}$. As a result, ethnic politicians could not 
reach compromises on very crucial issues, even if it was necessary for the whole country to continue its road toward the EU membership. As the EC concluded : « In BiH, nationalist rhetoric by key political leaders is challenging the arrangements established by the Dayton/Paris peace agreement and has stalled reforms. Much needed reforms of the police and of the constitutional framework have failed to make progress $»^{5}$. Yet, has the EU-related process not helped the country to become more democratic and stable?

\section{Bosnia and the European Union}

$\mathrm{BiH}$ and the European Union have been in deep economic and political relations more than a decade. That is, in the aftermath of the war in Bosnia which ended in December 1995 the European Union has intensified its strategic activities and programs towards the Western Balkans (hereinafter WB or Balkans) region in whole, including Bosnia. Also, the end of the war was the shift in the EU approach towards the Western Balkans in general and $\mathrm{BiH}$ in particular. That is, the EU proposed one after another the initiatives that were supposed to strengthen and speed up the European perspective of $\mathrm{BiH}^{6}$. The first such initiative came from France during its EU presidency in December 1996 within the framework of the so-called Royaumont Process. The initiative's central objective was the stabilization, democratisation, and peace-building in South-East Europe. Thus, the Royaumont Process was the first regional strategy towards the Western Balkans. Furthermore, the EU developed a regional approach launching a political and economic conditionality for the development of bilateral relations. Better to say, through the PHARE and OBNOVA humanitarian programmes, which started in 1997, for the first time in the region the EU initiated political and economic conditionality as its economic assistance under the mentioned initiatives was provided on condition that recipients respect human rights, democracy, and the rule of law ${ }^{7}$. This was a clear sign that the EU has changed its approach towards Western Balkans region and towards Bosnia from passive and incoherent to more active, committed, and united one. EU clearly showed his interest in resolving political, economic, and social problems that the whole region face.

7 Additionaly, in June 1998 the EU-BiH Consultative Task Force was established. Its major area of responsibility was to provide technical and expert advice in the field of judiciary, education, media, administration, and economy. In Susko's words, this event marked BiH official approximation towards the EU membership ${ }^{8}$. Furthermore, the same year in June the EU and BiH officials signed the "Declaration of Special Relations between EU and BiH". Then in 1999 the EU has initiated Stabilisation and Association Process (SAP) establishing more concrete and tangible political and economic links with the regional countries. Also, SAP was characterised by a twofold approach focusing on country-specific conditions on the one hand, and a regional approach towards the Western Balkans on the other'. In addition, the SAP became the centerpiece of the EU's long-term strategy towards the region of Western Balkans. The main objective of the SAP was to push democratic consolidation of the countries from the region through substantial domestic reforms which are based on European values and structures. Put differently, the SAP has been built on the idea of first stabilization of the region and its latter integration into the EU political and economic structures. The European Commission has put six key target areas into the SAP ${ }^{10}$ :

1. Development of existing economic and trade relations with and within the region; 
2. Development and partial redirection of existing economic and financial assistance ;

3. Increased assistance for democratization, civil society, education, and institution-building ;

4. Cooperation in the area of justice and home affairs ;

5. Development of political dialogue, including regional level ;

6. Negotiation of Stabilization and Association Agreements.

8 Thus, the regional shift in terms of integration emerged with the EU's clear commitment towards EU membership of the Western Balkans in 1999'11. In addition, in June 2000 in the Feira European Council, the EU member states decided that all the SAP countries, including Bosnia and Herzegovina, are potential candidates for future EU membership. Also, on 8 March 2000 the EU Enlargement Commissioner Chris Patten announced the Road Map for BiH as the first step in the framework of SAP. The document identified 18 initial steps which had to be implemented and which could lead to a feasibility study for a SAA with the EU. A new European partnership with Bosnia and Herzegovina was adopted by the Council on 18 February 2008. Because of a difficult and slow reform process, Bosnian government signed a Stabilisation and Association Agreement (SAA) with the EU in June 2008, which was the first pre-accession tool towards the country's EU membership ${ }^{12}$. The previous EU enlargement commissioner Olli Rehn called it "a milestone that marks a new stage in our relations" and "a gateway for $[\mathrm{EU}]$ candidacy ${ }^{13}$. Nevertheless, since that time little progress has been achieved due to inflammatory ethno-nationalist rhetoric. Also, slow and stagnant reforms in Bosnia are to some extent the result of a weak, passive, and uncommitted role of the international community, and especially the EU as central actor in Bosnia in past decade.

\section{Europeanization as a Theoretical Perspective}

Given the fact that Bosnia and Herzegovina has been more than a decade passing through deep and thorough European Union-related reform process, in the literature on European integration - so-called Europeanization process - the European Union is expected to develop more clear-cut and coherent strategy toward this EU aspirant country. Domm stresses that "the recommendation here is for the EU, aided by the EEAS, to move towards a more coherent, credible policy towards Bosnia $»^{14}$. Actually, Europeanization process is not only about adopting and implementing EU policies, rules, norms and values into the domestic economic, legal and political context. It is equally important that the EU sets clear standards, measures and rules which are to be adopted by aspirants on the membership. As Anastasakis and Bechev conclude, «the criteria and benefits of (EU) conditionality must be visible not just to the elites but also to the citizens, in order to sustain momentum for reform along the long and difficult road to accession $»^{15}$. Better to say, Europeanization process as a comprehensive reform and transformation oriented process is a two-way street between the European Union and the countries that aspire for the EU membership. That is why, it is of paramount importance that the roles and responsibilities both of the European Union and the EU aspirants, in this case Bosnia, be clearly defined and not left to political manipulation.

10 The idea of Europeanization has become very popular within the study of European integration. Since early 1990s the concept has been widely used by EU scholars in terms of analysing the EU's impact on its member states and generally in shaping global 
affairs. There have been a variety of definitions made in relation to Europeanization. However, most of them interpret this process as reform process in domestic political and economic system affected by policies decided at the European level. That is, we can define Europeanization as a kind of form of domestic change that is caused by European decision-making. Similarly, Radaelli defines Europeanization as "processes of (a) construction, (b) diffusion and (c) institutionalization of formal and informal rules, procedures, policy paradigms, styles, ways of doing things and shared beliefs and norms which are first defined and consolidated in the making of EU decisions and then incorporated in the logic of domestic discourses, identities, political structures and public policies $»^{16}$. However, very often it happens that European norms and values clash with EU aspirant's laws, values, and norms. As Rory Domm argues « despite the rhetoric, Europeanization, whereby vast numbers of detailed, non-negotiable rules are adopted by applicant countries, is hardly always consistent with local ownership $»^{17}$. As Pridham has shown on the example of Slovakia, although the demands from the EU may have a strong and positive impact on the democratisation in an applicant country, success still very much depends on a number of factors, including the determination of individual governments, strong public support for accession, and mutually supportive political dynamics in Brussels and the future member states ${ }^{18}$. Thus, it is of crucial importance that the EU find the way and develop solid methods how to diffuse and transmit its rules, policies, values and a European paradigm as an overall concept. The EU leaders are more than aware that there can be political groupings in any EU aspirant that do not want to accept each and every rule and standard coming from Brussels.

In addition, Europeanization is a logical extension of the EU integration theory. It gained special popularity among academic circles during the 1990 s and beyond ${ }^{19}$. Europeanization process may have two functions. First, it explains the influence of the European politics and institutions on the domestic politics. Second, Europeanization stresses the process of change through which domestic actors adapt to European integration. Such a Europeanization effect is best illustrated through the "basic paradigm", although very general one (Figure 1.1).

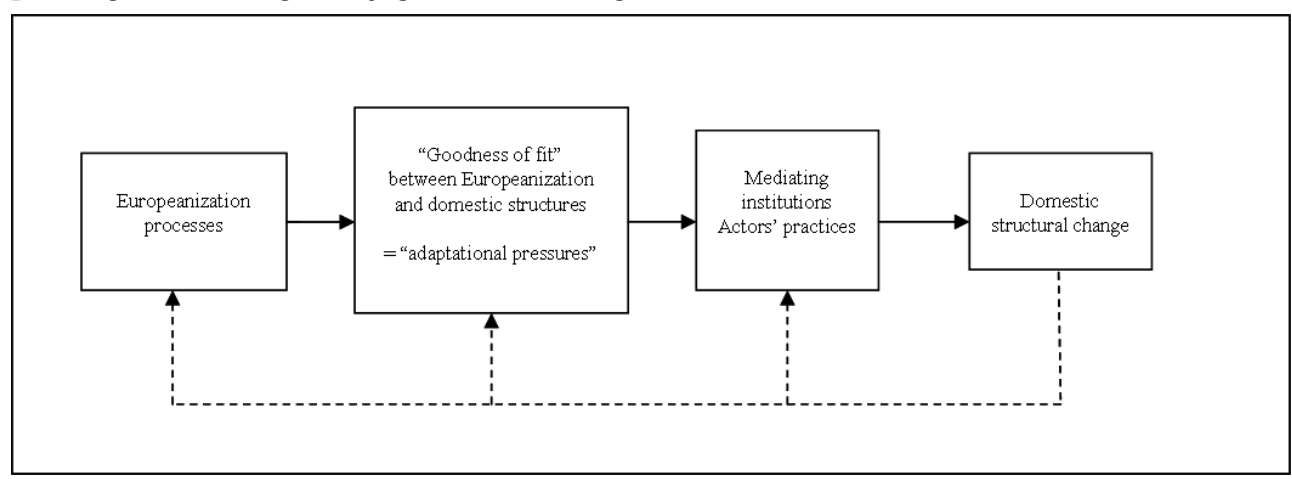

Figure 1.1 Europeanization and Domestic Change

Source : Risse (Thomas), Cowles (Maria G.), Caporaso (James), « Europeanization and Domestic Change : Introduction », in Cowles (Maria G.) et al., Transforming Europe. Europeanization and Domestic Change, Cornell University Press, 2011, p. 6)

12 The paradigm emphasizes that European integration leads to pressures in order to make necessary adjustments which are then influenced by domestic factors, and finally lead to outcomes ${ }^{20}$. Indeed, europeanization has critical transformative power in the 
member states. Here, degree of pressure created by the europeanization is of a crucial importance. This pressure is a function of the degree of fit (misfit) or congruence (incongruence) between "Europe" and the domestic level ${ }^{21}$. As a result, degree of fit or misfit leads to adaptational pressures. Simply put, if the EU policies and its standards are similar to those at the domestic level then pressure for reform is much lower. However, such pressure is a necessary but not a sufficient condition for reforms to be made by domestic actors ${ }^{22}$. For successful EU reform process to happen, the combination of a strong and united $\mathrm{EU}$ and a committed domestic factors is crucial.

\section{EU's Capability-Expectations Gap}

13 The literature of the European studies has been full of praise, potential and arguments perceiving the $\mathrm{EU}$ as a normative, civilian, humanitarian, and even military actor at the international stage. However, the most important thing here is to understand and evaluate practical relevance and concrete results of such academic statements. In other words, it is of utmost importance to measure and explain whether there is relevance between the idea of "European actorness" and tangible results achieved in practical delivery. In 1993 Christopher Hill analysed the European Union from the angle of its international role and came to conclusion that there is the so-called "capabilityexpectations gap" - between what the EU has been talking to be doing and what it is actually able to deliver in practice. Hill points out that the capability-expectations gap has resulted from three closely related factors : namely, the ability to agree, resource availability, and the instruments at the EU's disposal ${ }^{23}$. As Toje claims, "without capabilities and frameworks in place, the lack of agreement on foreign policy goals and the means by which they are to be attained could remain clouded in ambiguity ${ }^{24}$. That is, for the EU to promote itself as a capable and powerful actor in global politics it is important that it shifts from mere rhetoric about its "actorness" to resolving acute problems in world and in its neighbourhood. As Hill claimed, if the capabilityexpectations gap is to be closed, the notion of European international activities must be grounded in demonstrated behaviour rather than potential and aspirations ${ }^{25}$.

14 In this light, it is important to understand the role and potential of the EU to press for reform process in Bosnia in order to make this country a success story instead of the "sick man of Europe". To put it differently, without confronting Bosnian malaise seriously and constantly accusing the domestic ethno-nationalist political elites inflammatory rhetoric as a primary reason for years-long deadlock the EU is pursuing risky policy which describes it as a weak and not-serious-enough to challenge sensitive global problems.

In fact, eighty-eight percent of Bosnians support Bosnia's European ambitions, according to the poll conducted by the Bosnian agency for European integration for which 1200 people were questioned ${ }^{26}$. Furthermore, the poll results show that support for EU membership is strongest in Bosnia's Muslim (Bošniak) community with 97 percent in favor, while 85 percent of Bosnian Croats support it and 78 percent of Bosnian Serbs ${ }^{27}$. Such a significant number of supporters of EU integration among the citizens of all the three ethnic groups is an opportunity for the EU to prove its practical capabilities. However, there is a question mark whether the EU can meet the expectations of the Bosnian citizens. Does it have necessary tools and resources to help resolve Bosnian enigma? Therefore, as Hill stresses it is very important for all sides 
involved to measure the effectiveness of current europeanization process in Bosnia and sketch « a more realistic picture of what the Community (EU) .... does in the world $»^{28}$.

\section{The EU Conditionality in Bosnia and Herzegovina} which have established bilateral links with Brussels. Thus, europeanization reform process in aspirant countries such as Bosnia itself is to a large extent driven by the socalled EU conditionality that stimulates domestic reforms. In addition, the EU conditionality can therefore be understood as an "ad hoc acquis démocratique" which has been significantly shaped in the framework of the Copenhagen Criteria ${ }^{29}$. Specifically, the EU conditionality is based on "strict conditions" that the candidate or potential candidate countries have to meet in order to become full members of the $\mathrm{EU}^{30}$. As Schimmelfennig and Sedelmeier argue, «the dominant logic underpinning EU conditionality is a bargaining strategy of reinforcement by reward, under which the EU provides external incentives for a target government to comply with its conditions $»^{31}$ So far, the EU has established several strategic tools through which it attempts to press the process of institutional adjustment to EU standards and values. Overall, the EU conditionality in the Western Balkans, including Bosnia, is established by the following tools ${ }^{32}$ :

1. the general Copenhagen criteria - political, economic and acquis-related - applied to all candidate and potential candidate countries ;

2. the 1997 Regional Approach and the 1999 SAP ;

3. country-specific conditions to be met before entering the SAA negotiation phase and conditions arising out of the SAAs and the CARDS framework;

4. conditions related to individual projects and the granting of aid, grants or loans ;

5. conditions that arise out of peace agreements and political deals (e.g. Resolution 1244 of the UN Security Council, and the Dayton, Ohrid, and Belgrade agreements). to promote reform, to prescribe criteria attached to EU-granted benefits, and to differentiate among countries by assessing each on its own merit ${ }^{33}$. Although it is often taken for granted that EU member states possess wide-ranging conditionality power which can "naturally" press domestic officials to implement required EU-related agenda, it often results in opposite direction, as EU aspirants demonstrate significant level of resistance. That is, while many expected that europeanizing reform process will have critical impact on the crisis-driven western Balkans region and especially Bosnia as its very unstable part, the entire process resulted in fixed positions of ethnonationalists that are ready for Brussels only at a declaratory level. In addition, the idea that EU conditionality will work in Bosnia and solve its post-war political, economic and legal problems seems to result in complete disappointment as seen so far. In that regard, Sebastian points out that the EU jeopardized and failed to link the power and incentives inherent in its accession conditionality to the constitutional reform process in Bosnia ${ }^{34}$. As Noutcheva notes: in essence, the reforms demanded by the EU as conditions for establishing contractual relations with BiH link its membership prospects to changes in the internal state structure of $\mathrm{BiH}^{35}$. However, internal political agenda in Bosnia has not shifted to such an important extent towards the so-called "European agenda". It is also puzzling that although the EU has intensified its activities 
in Bosnia there have not been significant positive reforms regarding the EU reforms in the country.

\section{The European Union as a Main International Actor} USA, Russia, and China, EU is heavily involved in the political and economic affairs in the western Balkans and in Bosnia and Herzegovina in particular. During the Yugoslav wars in the early 1990s the EU had played very weak and incoherent role due to a serious lack of commitment and political will of its member states to pool more sovereignty in order to build stronger and more coherent security and defence policy at the European level. As Javier Solana points out, « when the Yugoslav wars broke out in the 1990s we watched as our neighbourhood burned because we had no means of responding to the crisis $»^{36}$. At the beginning of the Yugoslav crisis, the Luxembourg Foreign Minister Jacques Poos, then head of the EC Presidency, declared that the organization would intervene in Yugoslavia because it was «the hour of Europe, not the hour of the United States "; however, the opposite proved true since it was a diplomatic fiasco for Europe and a diplomatic and military domination of the USA. Famous Henry Kissinger's question, "what is Europe's phone number?», proved its relevance. What's more, only US leadership and initiative created the Dayton peace agreement in November 1995, ending a brutal three and a half year bloody war in Bosnia $^{37}$.

However, after the war the EU developed more strategic and tangible approach towards the Western Balkans countries. There has been an understanding that instability and possible conflicts in the region pose direct and serious threat to the EU. As a response, the EU developed more pro-active and comprehensive security and defence policy at the European level. As pointed out by Chris Patten, the European Commissioner for External Relations, «the dreadful humiliation Europe suffered in the Balkans in the early nineties also made us realise that Europe had to finally get its act together ${ }^{38}$. Among other things, in December 2004, the EU launched a peacekeeping military operation in BiH, replacing NATO's SFOR mission. In addition, the EU sent its Police Mission to Bosnia in January 2003 to replace the UN's International Police Task Force (IPTF) as part of the broader rule of law strategy in BiH and in the region. On the other hand, the US changed its diplomatic and military priorities and deployed most of its troops in Iraq and Afghanistan. Following initiation and later signing of SAA the western Balkan countries shifted from the US-dominated Dayton era into the EUdominated Brussels era. As Javier Solana, the former High Representative of the EU pointed out, the most fundamental objective of the EU at this transition stage is to move from "the era of Dayton " to "the era of Brussels $"^{39}$. However, the so-called Brussels era has not passed without challenges.

Following the US shift in its foreign policy of prioritizing other regions more than Bosnia, such development has left significant diplomatic space for other global powers such as the EU to assert its influence in this highly problematic country. As a result, Hadžikadunić believes that gradual withdrawal of the US from the western Balkans towards more critical world regions has signalized leaving the Balkans region to the $\mathrm{EU}$ as its natural and strong ally ${ }^{40}$. Thus, by formulating specific democracy-relevant conditions and identifying areas where democratic reforms were required, the EU

Balkanologie, Vol. XIII, n 1-2 | 2011 
initiatives became the main driving force behind democratisation in the Western Balkans and Bosnia as well. The EU thereby became the main actor of external democracy promotion in the region, with overlapping processes of europeanisation and democratisation ${ }^{41}$. Although the Union developed new institutional relations with the regional countries through newly initiated SAA, it has faced a lot of challenges, especially in Bosnia and Herzegovina. The SAA includes provisions and measures for future EU membership of the western Balkan countries. In fact, SAA is similar to the Europe Agreements that the EU signed with the Central and Eastern European countries in the 1990s and to the Association Agreement with Turkey. However, because of a long-lasting political malaise in Bosnia, it is obvious that the "EU's carrot" in the form of SAA has not worked with the local country's officials. In fact, Bassuener and Lyon in this light claim that not only did the SAA not generate momentum, but Republika Srpska (RS) is busy unravelling some of the hard-won gains of the previous 13 years, including reforms required by the EU as preconditions for signing the SAA ${ }^{42}$. That is why the leaders' duty is to make the bloc's values, norms, and standards more attractive and more concrete both for Bosnian politicians and its citizens.

Furthermore, the "EU sticks" have not been effective in interactions with the Bosnian political elites. Better to say, the EU has not developed adequate "stick policy" which could be applied to politicians, political parties, and organizations that support policies that are opposed to Euro-Atlantic integration principles and that question the state institutions. Thus, the EU foreign minister Lady Ashton has only recently demanded that her new Bosnian envoy, part of her newly created diplomatic service, be given new powers by the Council of EU foreign ministers to impose travel bans and asset freezes on obstructionist Bosnian politicians ${ }^{43}$. Even the EU financial aid directed at the country has not been enough motor force that would motivate domestic politicians to implement necessary measures that Brussels had set beforehand. For instance, the EU provides targeted assistance to candidates and potential candidates countries through IPA (Instrument for pre-accession assistance) which supersedes the five previously existing pre-accession instruments, PHARE, ISPA, SAPARD, Turkey instrument, and CARDS. Thus, the European Commission has allocated 440 million Euro of support to $\mathrm{BiH}$ in its transition from a potential candidate country to a candidate country for the period 2007-2011 under the IPA. BiH as a potential candidate is currently eligible for assistance to transition and institution building and cross-border cooperation. However, the EU has in some instances cut its financial assistance to BiH due to slow reform process. Thus, the EU has clearly demonstrated that very often it has been insensitive regarding the complexities and troubles of social and political context of Bosnia and Herzegovina.

\section{The EU's Central Bodies in Bosnia and Herzegovina}

The European Union has so far established bodies and instruments through which it attempts to speed up Bosnia on the road to full membership. One such body is the European Union Special Representative in BiH (EUSR) which is currently acting as a High Representative as well. In March 2001 Lord Paddy Ashdown was named as the first EUSR in BiH. The main and the most important duty of EUSR has been to help the BiH government in making EU reforms. As the Commission stresses, the mandate of the EUSR is to promote overall political coordination and offer the EU advice and 
facilitation to $\mathrm{BiH}$ to help the country meet necessary requirements for the $\mathrm{EU}$ membership ${ }^{44}$. The EUSR's Special mandate is derived from the European Union's policy objectives in Bosnia and Herzegovina. These include, in particular, helping achieve progress in implementing the Dayton Peace Agreement as well as in the Stabilisation and Association Process ${ }^{45}$. In addition, the EUSR regularly reports to the Council of the European Union, the inter-governmental body representing the $27 \mathrm{EU}$ member states, through the High Representative for the Common Foreign and Security Policy and Secretary-General of the Council. Thus, the EUSR has been of crucial importance to put pressure on domestic political leaders to continue with the EU-related reform process. However, due to vague position of the EU on the Bosnian crisis the EUSR has played unclear and ambiguous role.

Very often there has been serious imposition of reform process from the HR/EUSR on local politicians, and recent police reform has brought it to light. The Commission Feasibility Study published in November 2003 identified weaknesses in the policing system in BiH and concluded that it was necessary to " proceed with structural police reforms with a view to rationalizing police services $»^{46}$. As BiH political elites could not make compromise on the necessary reforms, the EUSR imposed the reforms on them and thus solved the deadlock. This finally enabled the EC to recommend the start of SAA negotiations with the BiH government on 21 October 2005. However, such an imposition was clearly a forced europeanizing reform. Previous HR Petritsch summarized the situation by stressing : «I furthermore wanted to move this country away from a situation where it seemed, that fundamental changes - at times even alien to its local traditions - were being simply imposed on this state and its citizens. More often than not - the country was treated as object" ${ }^{47}$. BiH future in the EU is thus highly uncertain and even problematic because of the underdeveloped domestic policymaking structures and serious marginalization of both political representatives and ordinary citizens from open democratic deliberation. That is, coerced Europeanization by the EUSR has prevented genuine democracy from flourishing. Thus, the EU is implicitly paralyzing active involvement in policy-making and political responsibility of the Bosnian politicians.

In addition, very often disunited position of the EU member states makes the role of the EUSR in BiH ineffective and weak. For instance, the status of the double-hatted OHR/ EUSR was sometimes very unclear and disputed. Thus, commenting on the appointment of Lord Ashdown as the EUSR, the EUPM official claimed that without dedicated EUSR staff, it was felt that "he was the right person for the job...but he never really was the EUSR" 48 . Also, another EUPM official put it that "the EUSR position was essentially irrelevant" ${ }^{49}$. This was the case when in January 2009, the international community's High Representative and the EUSR in Bosnia and Herzegovina unexpectedly announced his resignation in order to take up the post of Slovak Foreign Minister instead. From his early mandate he knew very well that his position was like 'riding a dead horse' as he used to say. Therefore, as Judy Batt points out, "the abrupt departure of HR/EUSR Lajcak has exposed drift and disarray in the EU's policy towards $\mathrm{BiH}^{\prime 50}$. It would not be far from truth to say that Lajcak did not have clear-cut message of support from Brussels which would help him to do his job effectively. As the International Crisis Group pointed out in its report, "there is some reluctance in Brussels for taking up such responsibilities, especially if it means deployment of the largest ever EUSR office, and increased EC funding" ${ }^{51}$. 


\section{European Union States Divided in Bosnia}

Very often the EU leaders seem very divided and deliver oppressing messages when the European integration reforms in Bosnia are concerned. In view of the former US Ambassador Charles English, "part of the problem is that the EU itself is divided about Bosnia. Among member states, only a handful, most notably the UK, appear to have a clear grasp of the dangers posed by Bosnia's current political dynamics" 52 . Probably the best demonstration and proof to this fact has been diverse views and opinions of the EU officials regarding the future design and content of the Bosnian constitutional framework. In fact, the Bosnian authorities are expected to implement the European democratic values and effective bureaucratic standards that are based on the Copenhagen and Madrid criteria, respectively. However, although the Copenhagen and Madrid criteria propose what are the standards and measures that have to be implemented by the Bosnian politicians, the EU member states have not demonstrated a common and principled position on the necessary constitutional changes. Thus, while EU officials have been vocal in their demands and calls for constitutional change, they have not been clear enough and committed about the specific requirements expected ${ }^{53}$. As a result, the EU member states are as divided as the local politicians are over the design and shape of the future Bosnian constitution. This has resulted in a huge EU credibility crisis in Bosnia. In this respect, Cohen argues that if the EU does not clearly support the progress that has already been made in the europeanization of the Western Balkan countries the European Union would surely pay a very high price ${ }^{54}$.

Over time there have even been different messages from the EU politicians and officials regarding the content and degree of reform within the country's constitution. To clarify, the European Commission President Barroso pointed out that while constitutional reform was not a strict condition for signing the SAA, «there is [a] link between these two processes ... The EC and EU have to be convinced that they have a partner in $\mathrm{BiH}$, which will be capable to respect its promises and implement the Agreement that we negotiate now $1^{55}$. Thus, this has been a sort of informal requirement that the EU officials expect from the Bosnian political representatives to implement reforms in order to speed up the whole European integration process. However, there have been a number of European leaders who do not support the idea that Bosnia needs a new or modified constitution in order to enter the EU family. For instance, Solana asserted in his speech «I do not think it would be a good idea to open Dayton again at this moment. Of course, if there is an agreement between the three sides on some arrangements or solutions, I would not be against it ... [but] I very much hope that as time goes by you will have the discipline and the energy to do this alone, without the need for pressure and impulse from the international community ${ }^{56}$. In addition, Werner Almhofer, Austrian Ambassador to BiH, claims that the European Union had never set the successful implementation of constitutional reforms as a condition for BiH's EU membership ${ }^{57}$. Better tosay, the EU authorities have perceived the constitutional reform as an informal conditionality without clearly stating rewards or punishments for $\mathrm{BiH}$ politicians.

Although the EU leaders have often stressed that $\mathrm{BiH}$ cannot realize its $\mathrm{EU}$ aspirations if it does not reform its constitutional framework, most of them have not demonstrated necessary commitment and political will to help Bosnia resolve its political deadlock.

Balkanologie, Vol. XIII, $\mathrm{n}^{\circ} 1-2$ | 2011 
That happened to a large degree due to diverse national interests of the EU member states on foreign policy questions and due to vagueness of the Copenhagen and Madrid criteria that are open to political manipulation. As Govedarica points out : «It is true that the EU has had no clear stance towards Bosnia. For a long time the EU officials have believed that the mere process of European integration will solve the country's problems. However, when it was clear that it was not the case then the EU could not find adequate alternative instrument ${ }^{58}$. Better to say, since the EU has not stressed clearly the measures required, the Copenhagen and Madrid criteria can be understood in thousands of different ways as is the case with the Bosnian elites. As a result, Bosnian Muslims want to enter Brussels as a country with strong and powerful central state. Bosnian Croats are in support of highly decentralized country. Bosnian Serb leaders see Bosnia in the EU as a weak central state with strong entities. That is why, the EU should treat Bosnian case differently from other EU aspirant countries. Put differently, Bosnia and Herzegovina with its long history of international protectorate, inter-ethnic conflicts, shifting borders and a recent brutal war, is not as other countries ${ }^{59}$.

\section{Failure of the Initiative for Dayton II}

Dayton Agreement established the Constitution of $\mathrm{BiH}$ in an annex, deciding on the division of the country into two Entities : the Bosniak/Croat Federation of BiH (mainly controlled by the Bosniaks and Bosnian Croats), and the Republika Srpska (mainly governed by the Bosnian Serbs). Both of the country's entities have their own political and governance structures. The Federation of $\mathrm{BiH}$ is divided into three levels: the entity level, the cantonal level, and the municipal level. The RS does not have a cantonal level, it only has municipalities. Overall, the DPA has succeeded in keeping BiH as an independent and sovereign country with a joint multi ethnic government. Thus, the current political system in Bosnia is a product and result of the Dayton Agreement. Also, one of the most important goals of the DPA, restoration of security and physical infrastructure, has been satisfactorily met. However, the broader objective of organizing a multi-ethnic, democratic, and economically self-sustaining country is still a long way away ${ }^{60}$. While the DPA brought the war to an end and laid the foundation for consolidating peace, many observers also believe that the agreement as a document reflects wartime circumstances and cannot by itself ensure BiH's future as a functioning and self-sufficient democratic state ${ }^{61}$. Also, even though the EU has repeatedly stated that constitutional reforms are neither a formal requirement for closing the OHR nor for Bosnia's entry into the $\mathrm{EU}$, the constitutional framework must provide stable and effective state structures able to deliver EU integration reforms ${ }^{62}$.

Since domestic politicians could not agree on necessary changes within the constitution, it has become more than obvious that external mediation, without a direct imposition of a model, is deadly required if any significant progress is expected. And this happened when the EU authorities decided to take decisive and concrete diplomatic lead in fixing Dayton and thus paving the way for a new era of functional, self-sustaining and democratic BiH. Thus, during the Swedish EU Presidency there has been such initiative on the constitutional reform on 10 October and again on 20-21 October, when Carl Bildt, Sweden's foreign minister, Olli Rehn, the European commissioner for enlargement, and Jim Steinberg, the US Deputy Secretary of State, called most of Bosnia's political party leaders together at Butmir, outside Sarajevo, 
where they outlined a "package" of reforms necessary, as they sold it, for deeper EuroAtlantic integration of their country ${ }^{63}$. In the medias, the meeting in Butmir was called "Dayton II" which best demonstrates its importance for the BiH future governance. However, it ended in complete failure. Bosnian Serb representatives rejected the proposed reforms as too drastic while Bosniak and Croat leaders described them as insufficient to solve the long-standing political stalemate. In this context, Bassuener and Lyon claim that « most of all, the EU needs to articulate clearly to both politicians and citizens what level of functionality $\mathrm{BiH}$ needs to have attained before becoming a viable candidate for membership in the EU, ... The EU must put forth a set of guidelines on what sort of $\mathrm{BiH}$ it can accept into its ranks, with clarity on what elements are unacceptable $»^{64}$. What is more, ambiguous and ill-prepared EU-US initiative at the Butmir NATO base just contributed to deepening of current crisis rather than resolving it $^{65}$.

Even though the EU and US seemed united and decisive in the Butmir process the whole negotiations ended in huge failure as domestic leaders could not be persuaded by the suggested measures. However, as Bosnia is for a long time passing from Dayton to Brussels era the EU is the most responsible actor for Butmir's constitution failure. As Joseph points out, "Washington's central policy challenge has shifted from getting the Bosnians to cooperate to goading the Europeans to act. Although Brussels has far more at stake than Washington does, and although it finally has a collective foreign minister, it still acts only when galvanized by the Americans or by crisis, or both ${ }^{66}$. The EU does not know how to behave like a global player when it comes to the Bosnian case. What's more, civil society was completely excluded from the Butmir negotiations. This was a clear threat to democratic deliberation that EU diplomats claim to be an important European value. Furthermore, the Butmir meeting has not even mentioned the controversial principle of entity voting, a voting principle in the constitution of $\mathrm{BiH}$, which is supposed to protect the interests of all three ethnic groups in the country. The power-sharing mechanisms based solely on the principle of ethnic identity and the permanent blocking of state institutions on the basis of the "national interests" of Serbs, Bosniaks and Croats by using the entity veto (entitetsko glasanje) within the Parliamentary Assembly of $\mathrm{BiH}$, turned out to be major obstacles for decision making in the country and for reforms needed in the context of EU integration ${ }^{67}$. Also, the EC clearly stressed that the "entity voting" has often prevented swift adoption of legislation which hinders country's rapid progress towards the EU membership ${ }^{68}$. Butmir negotiations clearly showed once again that Bosnia is a "difficult case" and that the international community, including the EU, will need to employ more energy and commitment in resolving "the Bosnian paralysis".

\section{Conclusions}

31 It is a natural part of the europeanisation process that the European Union goads Bosnian government to implement necessary economic, political, legal and administrative reforms as a part of the country's EU-related reforms through which it has been going through since late 1990s. However, Bosnia is for a long time in a serious political impasse due to different interests of the three ethnic communities regarding the future structure of the country's constitutional framework and the country in general. Additionally, the EU is equally responsible for the current status quo since its 
member states are not united in terms of proposed standards and measures expected from Bosnian government.

European leaders believe that mere process of europeanisation of Bosnia will bring stability, prosperity and genuine peace to the country. They expect the Bosnian political elites to make required changes including the question of a constitution that might satisfy all three ethnic communities. Yet, this is too a simplistic and unidimensional view with regard to complicated Bosnian political and social context. Although the Copenhagen and Madrid criteria propose what are the standards, values and norms that have to be implemented in the EU aspirants, the EU states have not sent clear messages regarding their expectations from the Bosnian political elites.As a result, $\mathrm{BiH}$ political elites effectively manipulate with reluctance opinions coming from the EU states. This is a serious credibility gap for the EU since it could not assert and prove itself as a strong and influential actor that is capable of solving "the Bosnian paralysis". Thus, leaving Bosnians to explore the options that befall a failed state located within Europe but on the margins of its prosperity and unity - is to simply acknowledge a bankruptcy policy ${ }^{69}$.

Despite the fact that the EU has utilized a number of strategic tools, instruments and institutions in the post-war Bosnia and Herzegovina in order to help the country's EU reform process, such an approach proved rather weak, ambiguous, and even unsuccessful. For instance, very often disunited position of the EU member states makes the role of the EUSR in BiH ineffective and highly invisible and weak - as it appeared with former EUSR Miroslav Lajcak. Furthermore, as a fundamental agreement, the SAA, has not generated expected reform processes and thus it should indeed be re-examined in order to make it closer to real needs of $\mathrm{BiH}$. Although it has become more than obvious that Bosnia is a different case from the Central and Eastern European countries' integration process, the EU has treated the country as any other. No doubt the EU leaders are often making the same mistake of ignoring the real problems of Bosnian state because they believe that mere process of European integration will make the country more democratic, stable and functional. Thus, the EU officials could make the same mistake from early 1990s since BiH ethnic leaders would manipulate with their reluctance and ignorance. As a result, the European officials have remained in a vicious circle between the "European values" and extremely opposing interests of the three ethnic elites in Bosnia. Batt warns that « the EU needs to rebuild its credibility in BiH by forging a unified position on a long-term strategy for the country, actively engaging in the constitutional reform process and giving more effective support to the next EUSR $»^{70}$. Thus, probably the newly lunched EU strategy of enhanced EUSR headed by Peter Sørensen, will prove capacity of the EU in helping Bosnia to resolve its political and social enigma.

\section{NOTES}

1. Šajinović (D.), « Nema razgovora dok se narušava Dejton », Nezavisne novine, 24/07/11 
2. Bassuener (Kurt), «How to pull out of Bosnia-Herzegovina's dead-end: A strategy for Success », Democratization Policy Council, February 2009, p. 1.

3. Mujkić (Asim), « We, the Citizens of the Ethnopolis », Constellations, 14 (1), 2007, p. 116.

4. Jarstad (Anna), "Dilemmas of War-to-Democracy Transitions», paper prepared for presentation at the conference State, Conflict, and Democracy, 12-13 May 2006 at Lund University (Sweden), p. 16.

5. European Commission, Commission Staff Working Document : Bosnia and Herzegovina 2007 Progress Report, Brussels, 6 November 2007, p. 5.

6. Hadžikadunic (Emir), Od Dejtona do Brisela, Sarajevo : ACIPS, 2005, p. 51.

7. Juncos (Ana E.), «The EU's post-Conflict Intervention in Bosnia and Herzegovina: (re)Integrating the Balkans and/or (re)Inventing the EU ? », Southeast European Politics, 6 (2), 2005, p. 96.

8. Šuško (Dževada), "EU Enlargement and the Case of Bosnia and Herzegovina: A Brief Historical Sketch », Journal of the Faculty of Arts and Social Sciences of Sarajevo, (2), Spring 2009, p. 104.

9. Džihić (Vedran), Wieser (Angela), «Incentives for Democratisation? Effects of EU Conditionality on Democracy in Bosnia \& Herzegovina ", Europe-Asia Studies, 63 (10), December 2011, p. 1805.

10. European Commission, The Stabilization and Association Process for countries of South-Eastern Europe, Brussels, 26 May 1999, COM (99) 235.

11. Aybet (Gulnur), Bieber (Florian), «From Dayton to Brussels : The Impact of EU and NATO Conditionality on State Building in Bosnia \& Hercegovina», Europe-Asia Studies, 63 (10) , December 2011, p. 1918.

12. Vucheva (Elitsa), « Bosnia signs EU pre-accession deal », Euobserver, 17/06/08.

13. Ibid.

14. Domm (Rory), « Next steps on Bosnia-Herzegovina : key elements to a revised EU strategy », Journal of Southeast European and Black Sea Studies, 11 (1), March 2011, p. 64.

15. Anastasakis (Othon), Bechev (Dimitar), «EU Conditionality in South East Europe : Bringing Commitment to the Process ", South East European Studies Programme (European Studies Centre, St Antony's College University of Oxford), April 2003, p. 5.

16. Radaelli (Claudio M.), "Wither Europeanisation? Concept stretching and substantive chance », European Integration Online Papers, 3 (7), 2000 (accessed online on February 5, 2011 at http://eiop.ot.at/eiop/comment/1999-007c.htm).

17. Domm (Rory), art.cit., p. 58.

18. Pridham (Geoffrey), "The European Union's Democratic Conditionality and Domestic Politics in Slovakia: The Meciar and Dzurinda Governments Compared », Europe-Asia Studies, 54 (2), 2002, p. 224.

19. Ladrech, (Robert), «Europeanization of Domestic Politics and Institutions. The Case of France », Journal of Common Market Studies, 32 (1), 1994 ; Borzel (Tanja), Risse (Thomas), "Conceptualizing the Domestic Impact of Europe", in Featherstone (Kevin), Radaelli (Claudio M.), eds.. The Politics of Europeanization, Oxford University Press, 2003.

20. Risse (Thomas), Cowles (Maria G.), Caporaso (James), art.cit. (figure 1.1), pp. 6-12.

21. Caporaso (James), «The Three Worlds of Regional Integration Theory », in Graziano (Paolo), Vink (Maarten P.), eds., Europeanization : New Research Agendas, Palgrave Macmillan, 2008, p. 29.

22. Borzel (Tanja), Risse (Thomas), art.cit., p. 58.

23. Hill (Christopher), "The Capability-Expectations Gap or Conceptualising Europe's International Role ", Journal of Common Market Studies, 31 (3), 1993, p. 315.

24. Toje (Asle), "The Consensus-Expectations Gap: Explaining Europe's Ineffective Foreign Policy ", Security Dialogue, 39 (1), 2008, p. 124.

25. Id., p. 123. 
26. Eubusiness, «Nine in 10 Bosnians want EU membership: poll », 24/03/11, www.eubusiness.com.

27. Kotonika (Mikel), «Waitlisted: The Western Balkans », Center for Strategic and International Studies, 05/04/11.

28. Hill (Christopher), art.cit., p. 306.

29. Domm (Rory), «Europeanisation without Democratisation: A Critique of the International Community Peacebuilding Strategy in Bosnia and Herzegovina ", Journal of Southeast Europe and Black Sea Studies, 7 (1), March 2007, p. 3.

30. Noutcheva (Gergana), «EU Conditionality, State Sovereignty and the Compliance Patterns of Balkan States ", Centre for European Policy Studies - paper prepared for the 3rd Pan-European Conference on EU Politics, European Consortium for Political Research, Bilgi University, Istanbul, 21-23 September 2006, p. 1.

31. Schimmelfennig (Frank), Sedelmeier (Ulrich), "Governance by conditionality: EU rule transfer to the candidate countries of Central and Eastern Europe », Journal of European Public Policy, 11 (4), August 2004, p. 670.

32. Anastasakis (Othon), Bechev (Dimitar), art.cit., p. 8.

33. Id., p. 1.

34. Sebastian (Sofia), "The Role of the EU in the Reform of Dayton in Bosnia-Herzegovina ", Ethnopolitics, 8 (3-4), September-November 2009, p. 344.

35. Noutcheva (Gergana), art.cit., pp. 1070-1071.

36. Solana (Javier), "EU makes its mark on the world stage ", Guardian, 11/10/09, www.guardian.co.uk.

37. Kim (Julie), «Bosnia : Overview of Current Issues", US Foreign Affairs - Defense and Trade Division. Congressional Research Service, Library of Congress, 16/06/08, p. 1.

38. Patten (Chris), «Europe in the World: CFSP \& its relation to development", speach delivered at Overseas Develoment Institute, 07/11/03, p. 2.

39. Solana (Javier), "The European Journey », Reporting Balkan Crisis Report, (493), April 22, 2004 (available at Institute for War and Peace, www.iwpr.net).

40. Hadžikadunić (Emir), op.cit., p. 23.

41. Džihić (Vedran), Wieser (Angela), art.cit., p. 1805.

42. Bassuener (Kurt), Lyon (J.), «Unfinished Business in Bosnia and Herzegovina : What Is To Be Done? ", United States Institute of Peace, May 2009, p. 2 (www.usip.org).

43. Waterfield (B.), « Baroness Ashton moves to take control of Bosnia », Telegraph, July 2010.

44. European Commission, Commission Staff Working Document, Bosnia and Herzegovina 2009 Progress Report accompanying the Communication from the Commission to the European Parliament and the Council, Enlargement Strategy and Main Challenges 2009-2010, Brussels, 14/10/09, p. 8.

45. EUSRBiH, «European Union Special Representative for BiH : EUSR Mandate », 2011 (Official Website of EUSRBiH, available at http://www.eusrbih.org/gen-info/?cid=2000,1,1).

46. European Commission, Report from the Commission to the Council on the preparedness of Bosnia and Herzegovina to negotiate a Stabilization and Association agreement with the European Union, Brussels, 18/11/03, available at www.dei.gov.ba, p. 26.

47. Petritsch (Wolfgang), "My lessons learnt in Bosnia and Herzegovina ", inBosnia and Herzegovina: Crossing from Dayton's to Brussels Phase and the Role of the International Community, Balkan Political Club : $9^{\text {th }}$ International conference (Sarajevo), 06/05/06, p. 4.

48. Mustonen (Jari), "Coordination and Cooperation on Tactical and Operational Levels: Studying EU-ESDP Crisis Management Instruments in Bosnia and Herzegovina », CMC Finland Civilian Crisis Management Studies, 1 (1), 2008, p. 20.

49. Ibid. 
50. Batt (Judy), «Bosnia and Herzegovina : the international mission at a turning point », FRIDE, Policy Brief, (5), February 2009, p. 1.

51. ICG, "Ensuring Bosnia's Future : A new international engagement strategy ", International Crisis Group, Europe Report, (180), 15/02/07, p. 27.

52. Tanner (Adam), « Bosnian Serb leader threat to stability : U.S. Cables », Reuters, April 2011.

53. Sebastian (Sofia), «Breaking the Impasse : Constitutional Reform in Bosnia », FRIDE, Policy Brief, (69), March 2011, p. 4.

54. Cohen (Lenard J.), " Detours on the Balkan Road to EU Integration », Current History, March 2009 , p. 129.

55. Barroso (Jose Manuel), "Discourse at the European Parlement ", European Commission, 14/06/06.

56. Solana (Javier), cited in $O H R$, BiH Media Round-up, 03/12/04.

57. Almhofer (Werner), « Bosnia and Herzegovina on the way to the EU - a view from Vienna? ", lecture at Sarajevo School of Science and Technology, 02/05/06.

58. Govedarica (Dobrila), "The Executive Director at Open Society Fund-Bosnia and Herzegovina », Personal Interview, May 2010.

59. Parish (Matthew T.), "The Demise of the Dayton Protectorate ", Journal of Intervention and State Building, (1), (Special Supplement), 01/12/07, p. 18.

60. Daalder (Ivo H.), Froman (Michael B. G.), « Dayton's Incomplete Peace” », Foreign Affairs, November-December 1999, p. 107.

61. Ashdown (Paddy), «A superb agreement to end a war, but a very bad agreement to make a state ", The Guardian, 02/11/05 (www.guardian.co.uk/article/o..i6064.8Q.oo.html).

62. Solioz (Christophe), Turning Points in Post-War Bosnia. Ownership Process and European Integration, Baden-Baden : Nomos, 2007.

63. Bassuener (Kurt), «It is Time for Plan B for Bosnia », European Voice, 22/10/09.

64. Bassuener (Kurt), Lyon (J.), art.cit., p. 13.

65. Bieber (Florian), «Constitutional reform in Bosnia and Herzegovina: preparing for EU accession ", European Policy Center, Policy Brief, April 2010, p. 1.

66. Joseph (Edward), «Bosnia and Herzegovina ", inWestern Balkans Policy Review, A Report of the CSIS Lavrentis Lavrentiadis Chair in Southeast European Studies, Center for Strategic and International Studies, September 2010, p. 62.

67. Bieber (Florian), Post-War Bosnia: Ethnicity, Inequality and Public Sector Governance, London : Palgrave, 2006 ; Džihić (Vedran), Ethnopolitik in Bosnien-Herzegowina: Staat und Gesellschaft in der Krise, Baden-Baden : Nomos, 2009.

68. European Commission, Commission Staff Working Document, Bosnia and Herzegovina 2009 Progress Report (op.cit.), p. 9.

69. Abramowitz (Morton), Hooper (James), «Re-repairing Bosnia after Dayton », Guardian, 18/03/10.

70. Batt (Judy), art.cit., p. 1.

\section{RÉSUMÉS}

Since early 1990s there have been a lot of scholarly works in which the European Union member states are challenged and criticized regarding a problem of their national division on global 
issues and not speaking "with a single voice" with regards to the EU's common foreign policy. Thus, national interests prevent the EU to become more credible, reliable and powerful actor on global scene. In a similar fashion, in this article I thoroughly explored approach and strategy that the European Union has applied towards Bosnia and Herzegovina within the framework of allembracing Europeanization process of $\mathrm{BiH}$ from the perspective of the EU's capacity and capability to influence domestic policy-making level. The article ends with the conclusion that the European Union member states are indeed divided, ambiguous, and weak in terms of its Europeanizing politics in Bosnia and Herzegovina thus further pushing the country into serious and deep political impasse and social tensions. As a result, such a strategy that the EU has utilised has proved that to a significant extent the EU itself is responsible for a decade-long status quo in the country since it is today having a role of international player from which Bosnian ordinary citizens have quite high expectations. Most importantly, that is about to result in a deep credibility gap for the EU since it could not assert and prove itself as an attractive, reliable, and powerful actor that is capable of resolving deep and harsh Bosnian paralysis.

\section{INDEX}

Keywords : Bosnia and Herzegovina, Bosnian Standards, Capability-expectations Gap, Credibility, European Criteria, European Union, Europeanization

\section{AUTEUR}

\section{BEDRUDIN BRLJAVAC}

Bedrudin Brljavac received his B.A. in Political Science and Public Administration at the Middle East Technical University in Ankara, Turkey. He completed the Master Programme in European Affairs (MEA) at Lund University in Sweden as the scholarship holder of the Swedish Institute. Since September 2011 he is the PhD candidate at the Department of Political Science at the University of Sarajevo. His doctoral project is titled « The European Union as a Global Civilian Power (GCP) : An Impact on the Transformation of Modus Operandi of the International Relations ». 